“Immigration and the Life Course," special issue, Canadian Studies in Population 40, no. 1-2 (2013): 75-88.

\title{
Unemployment of people of foreign origin in France: The role of discrimination
}

\author{
Jean-Luc Richard \\ Institut d'Etudes Politiques de Rennes-CNRS, UMR 6051 CRAPE, University of Rennes 1 \\ jean-luc.richard@univ-rennes1.fr
}

\begin{abstract}
This article has two primary objectives: (1) to understand the relationship between the origins of the children of immigrants and the likelihood of unemployment; and (2) to examine the possible role of discrimination in the likelihood of unemployment. The French Permanent Demographic Sample (EDP, a longitudinal database maintained by INSEE, which is the French equivalent of the English Longitudinal Survey) permits the study young foreign-born people who grew up in France and young people of foreign-origin who were born in France. The EDP is a census-based panel survey that, on average, comprises a 1 per cent sample of all immigrant groups. It contains information on a person's nationality relative to his/her labour market position. According to most academics, it also contains valuable socio-demographic and socio-economic information on parents and their sons and daughters. The data registry was created in 1967 and includes data from the 1968, 1975, 1982, 1990, and 1999 censuses. The interest in individual trajectories requires us to consider the relations between personal labour market situations and the acquisition of French nationality. This relation must be analyzed in light of the population which consists of those children who, since childhood, have been in a position to acquire French citizenship. Although gaining citizenship is usually regarded as an important sign of civic and political assimilation among immigrants, it can also be seen as a factor in their economic assimilation. French nationality makes it easier for young immigrants to get jobs. It is better to be a young Algerian or Moroccan with French nationality than to be a young Algerian or Moroccan who does not have French nationality.
\end{abstract}

Keywords: migrants' children in France, discrimination, labour market, longitudinal analysis, citizenship.

\section{Résumé}

Cet article a deux objectifs: étudier la relation entre l'origine des personnes issues de l'immigration étrangère en France et la fréquence des situations de chômage les concernant et examiner la rôle possible de la discrimination à leur encontre. L'Échantillon démographique permanent (EDP, une base de données longitudinale de l'Institut nationale de la statistique et des études économiques) permet l'étude des trajectoires des personnes issues de l'immigration qui ont grandi en France, qu'elles y soient nées ou non. L'EDP est une base de données dérivée du recensement, il comprend environ 1 de la population vivant en France. Cette base de données comprend des informations et variables sur la nationalité d'un individu et des informations sur sa situation sur le marché du travail. L'EDP contient aussi les informations pertinentes sur les parents et leurs enfants. Cette source statistique a été créée en 1967 et contient des données issues des recensements de 1968, 195, 1982, 1990 et 1999. L'intérêt porté aux trajectoires amène à considérer que les relations entre les situations sociales et l'acquisition de la nationalité française ne peuvent être analysées qu'à partir de la population qui a été, depuis l'enfance, susceptible d'acquérir la nationalité française. Cela impliquait la disponibilité de données longitudinales. Acquérir la nationalité française est généralement considéré comme un important signe d'intégration sociale et politique des personnes issues de l'immigration, mais cela est aussi un signe en faveur de leur intégration socioéconomique. Avoir la nationalité française favorise l'accès à l'emploi. Il est plus facile, pour un jeune d'origine marocaine ou algérienne d'obtenir un emploi si l'on a la nationalité française.

Mots-clés: enfants d'immigrants en France, discrimination, marché du travail, analyse longitudinale, citoyenneté.

\section{Introduction}

Discrimination in the labour market in France affects not only foreigners, but also French citizens of (or assumed to be of) foreign origin. ${ }^{1}$ Identifying and implementing efficient integration policies has become a very important issue on the agenda of European states. A French law passed in 2001 represents an important step in the

1. This article was written as part of an agreement between the French National Institute of Statistics and Economic Studies (INSEE) and the Centre of Research about Political Action in Europe (CRAPE - CNRS - University of Rennes 1). 
acknowledgment of the phenomenon which strengthened the legal basis for the fight against discrimination. ${ }^{2}$ An independent institution responsible for combating discrimination (HALDE: Haute autorité de lutte contre les discriminations et pour l'égalité) was set up in 2005 and recently transformed at the end of 2011. Despite these public policies, only a small number of statistical studies of differences in unemployment, with variables such as age and educational attainment corrected for, have been conducted into the situation of children of African migrants, and especially with regard to those whose parents were born in sub-Saharan Africa.

The French Permanent Demographic Sample (EDP, a longitudinal database maintained by INSEE and the French equivalent of the English LS) is the main French data source identifying the children of immigrants who are living in France. The EDP permits the indirect study of discrimination (Richard 1997a; Doomernik 1998; Constant 2005; Wacquant 2007; Maxwell 2010). Due to its size, it permits the analysis of child migrant populations: both young foreign-born people who grew up in France and young people of foreign origin who were born in France. The EDP is a census-based panel survey that, on average, comprises a 1-per cent sample of all immigrant groups. It contains information on a person's nationality relative to his/her labour market status. According to most academics, it also contains valuable socio-demographic and socio-economic information on parents and their sons and daughters (King et al. 2004). The available data registry was created in 1967 and includes data from the 1968, 1975, 1982, 1990, and 1999 censuses. In an initial panel study (Richard 1997b, 1990 data), we found that the low level of achievement of young immigrants in the labour market was due to the cultural and geographical origin of their parents, which was negatively correlated with labour market opportunities as other studies have confirmed (Brinbaum and Werquin 1997; Silberman and Fournier 1999; Silberman 2002; Meurs et al. 2007; Safi 2008). A considerable discrepancy between the performance of the children of European and North African immigrants has been systematically observed. The 1970s and 1980s represented an early phase for the reunification of existing and the formation of new Sub-Saharan African and Turkish families. The present study was undertaken in light of the increase in these new waves of immigration. ${ }^{3}$

\section{Qualifications and the Frequency of Unemployment}

The limited economic possibilities that have characterized the French labour market since the early 1970s have not been conducive to the economic integration of immigrants and their children. From 1945 to 1975, the growing labour market was the most important factor for the integration of immigrants. Today, school has taken over this role for the children of immigrants. However, the influence of school is undoubtedly less potent due to the potential discrepancy between the prospects of upward social mobility implicit in schooling and the reality of final professional outcomes. The problems experienced by the children of immigrants in this area need to be analyzed in light of the important role played by educational qualifications in mediating between the influence of family origin and career achievements. However, the need to take account of academic level does not mean that we can disregard the possible effects of family origin. Social and socio-demographic conditions explain the differences observed in terms of educational achievement (see Table 1). The fact that they perform at about the same level as native children from working-class families testifies to the school system's ability to integrate immigrant children to an extent similar to that of comparable "native" children whose parents are "French by birth."

2. Law No. 2001-1066, November 16, 2001, Journal Officiel, November 17, 2001. Initially, French laws referred primarily to equality between men and women and were later extended to prohibit any discrimination based on sex, religion, origin, opinion, age, family, or disability. The main principle is expressed in article L. 122-45 of the Labour Code and article 225-1 of the Criminal Code. As of 2001, article L.122-45 of the Labour Code prohibits and revokes any legislative act or provision that is based on origin, sex, customs, sexual orientation, family situation, political or social opinions, religion, etc. This article is based on the Law of November 16, 2001, which provided for a general principle of professional equality as an application of the European Directive dated November 27, 2000.

3. These groups were studied because they come from the countries and regions that are the largest source of immigration into France from outside of the European Union. Due to a law dating from 1872, the French Republic prohibits the conduct of censuses that distinguish between its citizens on the basis of their race or creed. No ethnic statistics are available in France, and the studies published by academics indicate that they do not believe that it is possible to construct and study ethnic groups (Oppenheimer 2008). Most people of foreign origin in France refuse to be considered as members of ethnic groups (see Simon and Clément 2006). This has an effect on the way French academics approach the writing of studies in English. 
Most university graduates from a North African background are female, which means that in the labour market they are labelled as both belonging to a "visible" minority and as women. Compared to other students, young people of "North African origin" appear to have repeated years of primary or secondary school more frequently. The youths in question have also often opted for a technological "baccalauréate" (i.e., "A-level" with a technological specialization) rather than an academic one. Native French people, in contrast, are more likely to take a more prestigious scientific "baccalauréate," even if they drop out without obtaining a qualification (Frickey

Table 1. Educational achievement (ages 20 to 29), 1999 percentages.

\begin{tabular}{|c|c|c|c|c|c|c|}
\hline & $\begin{array}{c}\text { Sons of } \\
\text { parents who } \\
\text { are "French } \\
\text { by birth" }\end{array}$ & $\begin{array}{l}\text { Daughters of } \\
\text { parents who } \\
\text { are "French } \\
\text { by birth" }\end{array}$ & $\begin{array}{l}\text { Children of } \\
\text { parents who } \\
\text { are "French } \\
\text { by birth" }\end{array}$ & $\begin{array}{c}\text { Children of } \\
\text { at least one } \\
\text { immigrant } \\
\text { parent }\end{array}$ & $\begin{array}{c}\text { Sons of } \\
\text { at least one } \\
\text { immigrant } \\
\text { parent }\end{array}$ & $\begin{array}{c}\text { Daughters of } \\
\text { at least one } \\
\text { immigrant } \\
\text { parent }\end{array}$ \\
\hline No qualification & 12.4 & 9.8 & 11.1 & 18.2 & 21.3 & 15.0 \\
\hline Primary School Level & 0.6 & 0.4 & 0.5 & 1.0 & 1.2 & 0.8 \\
\hline Secondary School Level & 6.2 & 5.9 & 6.1 & 6.9 & 7.4 & 6.5 \\
\hline $1^{\text {st }}$ certificate of apprenticeship & 13.7 & 7.2 & 10.5 & 10.7 & 13.2 & 8.1 \\
\hline $2^{\text {nd }}$ certificate of apprenticeship & 14.6 & 12.6 & 13.7 & 14.9 & 15.4 & 14.4 \\
\hline Technological Baccalauréat & 16.7 & 16.4 & 16.5 & 15.4 & 14.7 & 16.1 \\
\hline $\begin{array}{l}\text { General Academic } \\
\text { Baccalauréat ("A" level) }\end{array}$ & 10.9 & 14.0 & 12.4 & 11.5 & 9.4 & 13.8 \\
\hline Short University Education & 14.3 & 18.8 & 16.5 & 12.4 & 10.4 & 14.4 \\
\hline \multirow[t]{2}{*}{$\begin{array}{l}\text { University Bachelor's or } \\
\text { Master's Degree }\end{array}$} & 10.6 & 14.6 & 12.7 & 8.9 & 7.1 & 10.8 \\
\hline & $\begin{array}{l}\text { Born in } \\
\text { France and } \\
\text { at least one } \\
\text { immigrant } \\
\text { parent }\end{array}$ & $\begin{array}{l}\text { Born outside } \\
\text { France and } \\
\text { at least one } \\
\text { immigrant } \\
\text { parent }\end{array}$ & $\begin{array}{c}\text { Two } \\
\text { immigrant } \\
\text { parents from } \\
\text { North Africa }\end{array}$ & $\begin{array}{l}\text { Father } \\
\text { North-African } \\
\text { immigrant, } \\
\text { mother "French } \\
\text { by birth" }\end{array}$ & $\begin{array}{l}\text { Mother } \\
\text { North-African } \\
\text { immigrant, } \\
\text { father "French } \\
\text { by birth" }\end{array}$ & $\begin{array}{c}\text { Single-parent } \\
\text { family, parent } \\
\text { North African } \\
\text { immigrant }\end{array}$ \\
\hline No qualification & 16.6 & 2.5 & 16.3 & 15.5 & 13 & 25.1 \\
\hline Primary School Level & 0.8 & 1.6 & 1.1 & 0.7 & 3 & 1.3 \\
\hline Secondary School Level & 6.8 & 7.4 & 8.5 & 15.1 & 5 & 6.8 \\
\hline $1^{\text {st }}$ certificate of apprenticeship & 10.7 & 10.8 & 9.6 & 11.5 & 9 & 13.2 \\
\hline $2^{\text {nd }}$ certificate of apprenticeship & 15.4 & 13.4 & 16.8 & 16.8 & 10 & 20.9 \\
\hline Technological Baccalauréat & 15.7 & 14.4 & 15.6 & 14.2 & 16 & 9.6 \\
\hline $\begin{array}{l}\text { General Academic } \\
\text { Baccalauréat ("A" level) }\end{array}$ & 12.1 & 9.5 & 12.1 & 12.7 & 17 & 7.7 \\
\hline Short University Education & 12.8 & 11.1 & 11.9 & 11.8 & 15 & 9.6 \\
\hline $\begin{array}{l}\text { University Bachelor's or } \\
\text { Master's Degree }\end{array}$ & 9.1 & 8.3 & 7.3 & 9.5 & 11 & 5.8 \\
\hline \multirow[t]{2}{*}{$\mathrm{N}=$} & - & - & 3172 & 534 & 92 & 311 \\
\hline & $\begin{array}{c}\text { At least one } \\
\text { parent from } \\
\text { Sub-Saharan } \\
\text { Africa } \\
\end{array}$ & $\begin{array}{c}\text { At least one } \\
\text { parent from } \\
\text { South-East } \\
\text { Asia } \\
\end{array}$ & $\begin{array}{c}1 \text { or } 2 \\
\text { Turkish parents } \\
(95 \text { per cent } \\
\text { with } 2) \\
\end{array}$ & & & \\
\hline No qualification & 9.9 & 11.8 & 30.8 & & & \\
\hline Primary School Level & 1.1 & 0.5 & 2.7 & & & \\
\hline Secondary School Level & 9.6 & 10.2 & 8.9 & & & \\
\hline $1^{\text {st }}$ certificate of apprenticeship & 6.8 & 4.3 & 13.9 & & & \\
\hline $2^{\text {nd }}$ certificate of apprenticeship & 17.3 & 9.7 & 15.9 & & & \\
\hline Technological Baccalauréat & 19.3 & 15.0 & 5.7 & & & \\
\hline $\begin{array}{l}\text { General Academic } \\
\text { Baccalauréat (“A" level) }\end{array}$ & 16.4 & 16.9 & 13.5 & & & \\
\hline Short University Education & 11.6 & 14.5 & 7.0 & & & \\
\hline $\begin{array}{l}\text { University Bachelor's or } \\
\text { Master's Degree }\end{array}$ & 7.9 & 16.9 & 1.5 & & & \\
\hline $\mathrm{N}=$ & 353 & 372 & 473 & & & \\
\hline
\end{tabular}

Source: INSEE, Echantillon démographique permanent 1990-1999. 
et al. 2005). Overall, young women are characterized by a higher average educational level than young men of the same origin. This phenomenon is observed in all populations grouped together on the basis of the national or geographical origin of their parents.

Whatever their country of origin, immigrants and their children are integrated rapidly in terms of linguistic practice, culture and leisure activities, and demographic behaviour. This is in striking contrast to the difficulties they experience in achieving integration in the labour market due to the erosion of job opportunities during the 1980s and 1990s. Job-seeking among young people of foreign origin should be viewed more specifically in light of changing opinions about the immigrant population in general, and the descendants of immigrants in particular. If it is accepted that certain employers may discriminate, it is important, when measuring the likely magnitude of this phenomenon, to make a distinction between the consequences of discrimination in a balanced labour market and its consequences in a labour market with a labour supply surplus. In the former case, when unemployment levels are low in a society and its labour market, discrimination is identified by studying the "training/job occupied" or social mobility relation, since the level of unemployment is too low to identify discriminatory practices by comparing unemployment rates.

\section{Wage Differences}

The study of wage differences between individuals with the same level of qualifications is therefore a typical stage in the analysis. This approach has been developed in the United States where the unemployment rate is considerably lower than in France. During the employment crisis that has been emerging from 1975 onwards, corporate demand for labour has been too low to ensure a balanced labour market. The young working population has been hit particularly hard by this situation, since firms with openings tend to prefer to hire personnel with previous professional experience. Both young people of foreign origin and young people born of long-standing French families have been subject to the economic fluctuations and structural underemployment (see Table 2).

However, this problem primarily affects immigrants from North Africa, whereas it has as yet failed to have an effect on immigrants of Portuguese origin, for example (Richard 2003). In 1999, the percentage of young male children of Algerian migrants (20-29 years old) looking for a job was 29 per cent. This is the reason why the percentages given correspond to a proportion of unemployed individuals within the various sub-populations, whether they are of different national origin or not, rather than to the unemployment rate in the economic sense of the term. The overall group of individuals not present in the labour forces is therefore included in the total number used as the fraction denominator. The resulting value therefore helps reveal the real scale of youth unemployment. As 42 per cent of these young men of Algerian origin were in work in 1999 (and the others were "not part of the labour market," i.e., often "students"), the unemployment rate in 1999 was 41 per cent (see Table 2). The level of unemployment in this group is higher than can be explained on the basis of their average level

Table 2. Percentage of unemployed persons and the unemployment rate in 1999, aged 20 to 29.

\begin{tabular}{lcc}
\hline \multicolumn{1}{c}{ Origin } & Percentage unemployed & Unemployment rate (per cent) \\
\hline Children of 2 parents "French by birth" & 13 & 18 \\
Men & 11.5 & 15 \\
Women & 14 & 21 \\
\hline Algerian origin & 27 & 39 \\
Men & 29 & 41 \\
Women & 24 & 37 \\
\hline Sub-Saharan origin & 20 & 35 \\
Men & 19 & 33 \\
Women & 22 & 37 \\
\hline Moroccan origin & 23 & 38 \\
Men & 26 & 40 \\
Women & 19 & 34 \\
\hline Tunisian origin & 19 & 30 \\
Men & 20 & 31 \\
Women & 17 & 28 \\
\hline
\end{tabular}

Source: INSEE, Echantillon démographique permanent, 1990-1999. 
of training, and the fact that people of foreign origin are not permitted to fill public posts. The proportion of Algerian citizens looking for a job is, at that time (1999), 35 per cent and the unemployment rate among this same group during the same period is approximately 48 per cent (40 per cent in the case of French nationals of Algerian origin, who constitute almost all the young adults of Algerian origin born in France). A very similar rate of unemployment can be observed among men of Moroccan origin (26 per cent are unemployed, unemployment rate is 40 per cent). In comparison, among adults whose parents are French by birth, the unemployment rate is 18 per cent: 15 per cent for men, 21 per cent for women. These differences in unemployment rates are often thought to be due to discrimination, and a more sophisticated analysis involving statistical regressions will be used in order to examine this hypothesis below.

Young women of Algerian descent are less likely to apply for a job than men of the same origin (24 per cent of women, although this lower frequency is due to the fact that women may withdraw from the labour market in order to devote themselves to domestic and family tasks, as they become discouraged by the difficulties they encounter when looking for employment). Nineteen per cent of young women who have Moroccan immigrants as parents are job seekers (the fact that 36 per cent of them have a job increases the unemployment rate 34 per cent; see Table 2). The unemployment rate of children of Tunisian immigrants is 20 per cent (43 per cent do have a job). For these young people, the fact of being a French citizen is a status which facilitates access to employment. Among women of the same origin, the unemployment rate is equal to 28 per cent (17 per cent are applying for jobs, 43 per cent do practice a profession). Nevertheless, we cannot exclude the possibility that the prevalence of high rates of unemployment could have repercussions in terms of individuals choosing to prolong their education. No one who has student status (excluding post-graduates) can simultaneously be a job-seeker, even though many students and pupils leave the education system at all levels to enter the labour market when they are offered what they feel to be a suitable employment contract.

It is therefore both appropriate and useful to reason in terms of the probability of the individuals in a given population group $A$ being unemployed (we consequently refer to the percentage of unemployed individuals in the total population), rather than in terms of the unemployment rate among the working population made up of population group $A$. It is therefore important to remember that high unemployment rates do not imply a higher frequency of unemployed individuals among these young generations than those observed among older individuals. During the 1980s and 1990s, the increase in the unemployment rate among under-25s in France was nevertheless more than proportional to the increase in the number of job-seekers in this young population.

In both 1990 (Richard 2004) and 1999, the probability of immigrants being unemployed was greater the more recently they had taken up residence in the country. This factor, however, was less important in 1999, especially if we consider only the unemployment rates and not the frequency of occurrence of employment statuses among entire generations, including students. In fact, by 1999 the effect of age of arrival in France had fallen to a low level. Young adults having at least one immigrant parent from sub-Saharan Africa are often considered to be victims of stigmatization, for reasons in North America that are frequently referred to as "racial profiling." EDP data confirm the accuracy of this observation, particularly for women. Such women experience problems that are even more acute than those faced by young women of Algerian descent, with unemployment rates running at about 40 per cent (41 per cent for young men of Algerian origin, a figure which is 6 per cent higher than for young active males with parents from sub-Saharan Africa). Indeed, about 29 per cent of men of Algerian origin were job seekers in 1999, compared to 13 per cent among children with two parents who were "French by birth" (11.5 per cent for men, 14 per cent for women). In contrast, young men who have a Turkish father and/or mother do not seem to be widely stigmatized (16.5 per cent are looking for a job, i.e., employment rate of about 20 per cent, since 6 per cent do occupy professional positions). The situation is worse for women whose parents come from Turkey, with 21 per cent of them being unemployed and 41 per cent working in businesses or the public sector (Table 1). Another analysis (whose data is not reported in this article) also shows that young people born into the families of Asian or European immigrants do not seem to be penalized in the French labour market.

It is obvious that some companies have policies that discriminate against young people of foreign origin, especially Algerian children in the case of North African Muslims, and test surveys have confirmed that this is indeed the case (Amadieu 2005). For 30 years, young people of African descent have widely suffered from practices of this sort which violate their basic rights. Formal equality does not necessarily bring about "actual equality," and there are no "sectional pseudo-markets" in the "fragmented labour market" to enable candidate workers to enter independent markets. 
The economic reasons that could lead an employer to practice this type of discrimination may be associated with the anticipated negative consequences of hiring a certain category of manpower. Some company heads, especially in the service sector, may therefore consider, for reasons of prestige or image or out of fear of losing market share, that it is economically more profitable to employ certain individuals rather than others, independently of the comparative qualities and productivity levels of the respective manpower. An employer preference for discrimination in an economy with fixed or regulated wages results in a general absence of wage differences between immigrants and natives in equivalent jobs. This situation results in differences in unemployment rates. In our previous study examining the children of migrants, we stated that "the EDP reveals that they are faced with discrimination, especially in a shrinking labour market in which competition is strong and employers can afford to be 'choosy"' (Doomernik 1998: 38-39).

The previous argument raises a key point. Economists have formulated an explanation for unemployment based on the effects of hysteresis, according to which a phenomenon may persist even when its causes have disappeared (Elmslie and Sedo 1996). More fundamentally, in the labour market, temporary unemployment thus becomes persistent unemployment under the dual impact of the presumed erosion of skills of the unemployed and of company policy (Fitoussi et al. 2004: 1-4). The "theory of statistical discrimination" leads to equivalent results based on a different initial assumption. Some sort of "statistical discrimination" that is at work prevents young adults who are children of immigrants from achieving their full potential. The idea here is that employers are not in possession of all the relevant information and are therefore unable to perform an accurate ex-ante measurement of the real productivity of workers in certain minorities. Given these circumstances, discrimination exists in the hiring of workers based on risk aversion. This "theory of statistical discrimination" was formulated in part by K.J. Arrow (1972) and, with reference to the possible effect on unemployment rates within population groups, by E.S. Phelps (1972), M.S. Goldberg (1978), and G.J. Borjas (1990).

\section{Statistical Methods and Results}

When studying the causes of unemployment and the variables that are closely associated with it, logistic regression analysis offers a useful way to help gain an understanding of the complexity of the effects. Any analysis of behaviour that is limited to the observation of bivariate frequency tables in which a state is broken down according to one or more criteria risks being incomplete. Various structural effects may lead to erroneous interpretations of the observed phenomena. The importance of the specific effect of one variable may be incorrectly understood.

We must now undertake a more detailed study in order to isolate the specific effects of each individual factor, while assuming that all else remains constant. The variables contained in the EDP are essentially discrete qualitative, polytomous variables that may or may not be ordered. In this context, it is not possible to use the correlation analysis method. Logistic regression analyses are therefore a suitable way of showing the effect of each of the variables liable to be involved in the occurrence of a situation. The main individual characteristics are taken into account: national origin, current citizenship, place of birth, possibly the date of migration to France, social background of the family of origin, and individual qualifications of the young people and their parents (professional occupation, qualifications). The use of separate models for the male and female populations is necessary, of course, first of all because we need to understand the specific logic at work in the labour market. ${ }^{4}$ However, since it seems reasonable to consider that national origin is likely to account for much of the difference in unemployment rates between groups, it is necessary for the models to include variables that might influence employers' choices. Many public opinion surveys have shown the scale of the feelings of discrimination felt by numerous French citizens of North-African descent (Tiberj and Brouard 2005). The daughters of Sub-Saharan immigrants are the women who suffer the most from discrimination (see Table 3).

It is obvious that the biographical dimension of the integration process necessitates a research approach that goes beyond "ethnic belonging" in its attempt to understand individual outcomes (Blum 2002). Although ethnic markers are part of an individual's make-up, they also interact with other dynamic factors. The approach we use takes account of the individual's experience and personal or family history. The higher unemployment rate for

4. In this article, we present only a few of the many produced model tables. The different reference situations were chosen in light of the need to present convergent models for which both consistent statistics and probability results that are simple to interpret can be published. 
Table 3. Logistic regression. Frequency of unemployment among young active women (aged 23-29). Daughters of two parents who are "French by birth" $v$. women with at least one North African immigrant parent.

\begin{tabular}{|c|c|c|c|c|c|c|}
\hline & $\beta$ & $\sigma \beta$ & $t$ & $P$ & $P-P o$ & $\Delta(\%)$ \\
\hline Constant $=-0.584^{*}$ & & 0.336 & -1.74 & $36 \%$ & & \\
\hline Age: marginal effect of one more year & $-0.037 * *$ & 0.010 & 3.53 & $35 \%$ & $-1 \%$ & $-2 \%$ \\
\hline Foreign citizenship 1999 & $0.291 *$ & 0.155 & 1.87 & $43 \%$ & $7 \%$ & $19 \%$ \\
\hline \multicolumn{7}{|l|}{ Family origin } \\
\hline 2 parents French by birth & 0.053 & 0.204 & 0.26 & n.s. & n.s. & n.s. \\
\hline At least 1 Tunisian imm. parent & Ref. & Ref. & Ref. & Ref. & Ref. & Ref. \\
\hline At least 1 Moroccan imm. parent & 0.257 & 0.230 & 1.12 & n.s. & n.s. & n.s. \\
\hline At least 1 Algerian imm. parent & $0.487^{* *}$ & 0.217 & 2.25 & $48 \%$ & $12 \%$ & $33 \%$ \\
\hline \multicolumn{7}{|l|}{ Family size in 1990} \\
\hline 1-2 children & $-0.109 * *$ & 0.043 & 2.56 & $33 \%$ & $-2 \%$ & $-7 \%$ \\
\hline $3-4$ children & Ref. & Ref. & Ref. & Ref. & Ref. & Ref. \\
\hline $5-6$ children & $0.139 *$ & 0.081 & 1.78 & $39 \%$ & $3 \%$ & $9 \%$ \\
\hline 7 children or more & -0.020 & 0.128 & -0.16 & n.s. & n.s. & n.s. \\
\hline \multicolumn{7}{|c|}{ Occupation of the household's reference person } \\
\hline Farmer/Farm worker, father 1990 & -0.105 & 0.128 & 0.82 & n.s. & n.s. & n.s. \\
\hline Shopkeeper/Craftsman, father 1990 & -0.050 & 0.072 & -0.69 & n.s. & n.s. & n.s. \\
\hline Mgr./teacher/researcher, father 1990 & 0.020 & 0.074 & 0.27 & n.s. & n.s. & n.s. \\
\hline Middle management, father 1990 & Ref. & Ref. & Ref. & Ref. & Ref. & Ref. \\
\hline Employee/Clerk, father 1990 & $0.158^{* *}$ & 0.074 & 2.14 & $40 \%$ & $4 \%$ & $10 \%$ \\
\hline Manual worker, father 1990 & $0.236^{* *}$ & 0.078 & 3.03 & $41 \%$ & $6 \%$ & $16 \%$ \\
\hline Domestic employee, oth. situation 1990 & 0.014 & 0.055 & 0.25 & n.s. & n.s. & n.s. \\
\hline Married 1999 & $-0.262 * *$ & 0.048 & 5.43 & $30 \%$ & $-6 \%$ & $-16 \%$ \\
\hline \multicolumn{7}{|l|}{ Number of own children (1999) } \\
\hline None & Ref. & Ref. & Ref. & Ref. & Ref. & Ref. \\
\hline 1 child & $0.611^{* *}$ & 0.046 & 13.38 & $51 \%$ & $15 \%$ & $42 \%$ \\
\hline 2 children or more & $0.238^{* *}$ & 0.051 & 6.490 & $41 \%$ & $6 \%$ & $16 \%$ \\
\hline \multicolumn{7}{|c|}{ Educational attainment- Qualifications 1999} \\
\hline No qualification & Ref. & Ref. & Ref. & Ref. & Ref. & Ref. \\
\hline Primary Leaving Certificate & -0.022 & 0.224 & 0.10 & n.s. & n.s. & n.s. \\
\hline Secondary School Level ('O’ level) & $-0.188 * *$ & 0.091 & 2.07 & Ref. & Ref. & Ref. \\
\hline 1st certificate of apprenticeship & $-0.137 *$ & 0.075 & 1.82 & $33 \%$ & $-3 \%$ & $-9 \%$ \\
\hline 2nd certificate of apprenticeship & $-0.191 * *$ & 0.069 & 2.78 & $32 \%$ & $-4 \%$ & $-12 \%$ \\
\hline Baccalaureate ('A’ level) & $-0.554 * *$ & 0.063 & 7.90 & $24 \%$ & $-12 \%$ & $-32 \%$ \\
\hline University education & $-1.034 * *$ & 0.064 & 12.79 & $13 \%$ & $-23 \%$ & $-64 \%$ \\
\hline$\%$ concordance & $6 \%$ & & & & & $\mathrm{~N}=21,634$ \\
\hline
\end{tabular}

Source: EDP INSEE 1999. Notes: In this and subsequent tables, the following definitions apply: $\beta \mathrm{o}=$ intercept;

$\beta i=$ coefficient of regression of the variable; $\sigma \beta=$ standard error of $\beta ; \mathrm{Po}=$ probability associated with $\beta \mathrm{o}$, the constant estimated by the model; $\mathrm{DP}=$ marginal effect $(=[\mathrm{P}-\mathrm{Po}] / \mathrm{Po}) ;$ Ref. $=$ Reference category; $\mathrm{P}=$ probability associated with $\beta \mathrm{i}$;

Statistical significance: $* *=0.05 ; *=0.1 ;$ n.s. $=$ non-significant difference. $\mathrm{t}=$ Student's $\mathrm{t}$; $\mathrm{N}=$ number of observations.

individuals from large families reflects the fact that a certain number of young people from these families have to seek work to supplement their households' incomes, even though they often lack the level of education necessary to secure a job.

The interest in individual trajectories requires us to consider the relations between personal labour market situation and the acquisition of the French nationality. This relation must be analyzed in light of the population which consists of those children who, since childhood, have been in a position to acquire French citizenship. Any such analysis requires the existence of longitudinal data such as those provided by the EDP. The decision by immigrants to return to their country of origin is sometimes prompted by the problems they and their children experience in becoming integrated into French society. The Permanent Demographic Sample makes it possible to measure the number of departures from France and the number of young people of immigrant descent who are granted French nationality. Young immigrants born outside France are more likely to leave France than the other children of immigrants. For example, among the sons and daughters of migrants who arrived during the period 
1970-1979, 36 per cent of the foreign-born people of Sub-Saharan African origin present in France in 1990 were no longer living in France in 1999 (the corresponding level for people of the same origin but born of migrant parents living in France was 15 per cent). This phenomenon of departures from France has been analyzed in other studies (Richard 1998, 2007). Such departures are more frequent among families that arrived during recent waves of immigration, and in particular among people (and their children) who have lived in France in situations of great uncertainty and have been affected by unemployment. In particular, it is young immigrants who are the least well integrated in the labour market that have left. In consequence, after ten years or more of residence in France, neither the fact of having been born outside of France nor any particular age of arrival in France has any great effect on the probability of being employed. The same observation has already been made in France on the basis of the 1975-1990 data reported by the Permanent Demographic Sample (Richard 1997b: 258-260).

Logit models are very useful for understanding the complexity of the effects involved in situations of unemployment (Tables 3 to 6). Each model takes account of the most important individual characteristics: national origin, current citizenship, place of birth, possibly the date of migration to France, social background of the family of origin, and individual qualifications of the young people and their parents (professional occupation, diplomas). It is, of course, necessary to use separate models for the male and female populations from each of the main groups of origin, in order to identify the specific logic that characterizes the labour market. The models reveal the penalizing effect of being a mother of young children. The national or regional origin of the parents seems to be the reason that accounts for the greatest level of difference in unemployment rates between the groups. These analyses involve multivariate regression models employing interesting demographic, economic, and cultural variables on the basis of the EDP data. It is obvious that the biographical dimension of the integration process necessitates a research approach that goes beyond "ethnic belonging" in its attempt to understand individual outcomes. ${ }^{5}$ Separate models have been produced for women and men because of the effect that being a mother has on the probability of finding a job. Tables 3 and 5 show that the mothers of children are indeed more frequently unemployed.

Gaining citizenship is usually regarded as an important sign of civic and political assimilation among immigrants, but it can also be seen as a factor in their economic assimilation. French nationality makes it easier for young immigrants to get jobs. It is better to be a young Algerian or Moroccan with French nationality than to be a young Algerian or Moroccan who does not have French nationality. Thus, one must not overlook the role that nationality plays with respect to employment access, especially for women (see Tables 3 and 5). It must therefore be considered as an intermediate step,

"one that strengthens integration, in particular in its socio-economic aspect. It can be assumed that naturalization affects immigrants' status in the labour market and, in particular, their ability to secure a job, due to a range of reasons. When an immigrant gains French nationality, the range of jobs available to him opens up, to include in particular all of the jobs requiring French nationality. At the same time, it can be assumed that the immigrant can more easily circumvent discriminatory situations during the hiring process. Several empirical studies have revealed such forms of discrimination" (Fougère and Safi 2009).

The percentage given at the bottom of the table also indicates the quality of the regression (percentage agreement between the estimated situations and the observed situations). The quality of a logistic regression can be judged using other criteria and coefficients calculated using statistical programs. These tests should lead to the rejection of the Ho null hypothesis, defined such that the model contains no significant explanatory variable.

The formulae used to calculate the probabilities that measure the penetration rate of a state in the population are:

$$
P(0)=1 /(1+\exp (-\beta o))
$$

where $\beta o$ is the constant estimated by the model. The probability of an individual $x$ deviating from the situation made up of all the reference states by variables $x_{i}, x_{j}$, and $x_{k}$ is:

$$
P(x)=1 /(1+\exp -(\beta o+\beta l+\beta j+\beta k)) .
$$

There is therefore no additivity of deviation effects for the probabilities, but only for the $\beta$ i coefficients. It is thus possible to calculate the variations in probabilities resulting from state changes/differences. The significance of the $\beta \mathrm{i}$ parameters is established through the use of a Student's $t$-test $(t)$. Each $t_{i}$ is compared with the $t$ values as-

5. Richard 1997a: 258-260. 
Table 4. Logistic regression. Frequency of unemployment among young men (aged 24-29) in 1999. Sons of two parents who are "French by birth" v. men with at least one African immigrant parent.

\begin{tabular}{|c|c|c|c|c|c|c|}
\hline & $\beta$ & $\sigma \beta$ & $t$ & $P$ & $P-P o$ & $\Delta(\%)$ \\
\hline Constant $=-1.867 * *$ & & 0.107 & 17.42 & $13 \%$ & & \\
\hline \multicolumn{7}{|l|}{ Age (1999) } \\
\hline 24 & -0.091 & 0.075 & 1.22 & n.s. & n.s. & n.s. \\
\hline 25 & -0.052 & 0.071 & 0.73 & n.s. & n.s. & n.s. \\
\hline 26 & Ref. & Ref. & Ref. & Ref. & Ref. & Ref. \\
\hline 27 & -0.097 & 0.072 & 1.34 & n.s. & n.s. & n.s. \\
\hline 28 & $-0.149^{* *}$ & 0.075 & 1.97 & $12 \%$ & $-2 \%$ & $-12 \%$ \\
\hline 29 & $-0.251 * *$ & 0.081 & 3.11 & $11 \%$ & $-3 \%$ & $-20 \%$ \\
\hline Foreign-born & -0.064 & 0.190 & -0.34 & n.s. & n.s. & n.s. \\
\hline Foreign citizenship 1999 & 0.194 & 0.126 & 1.54 & n.s. & n.s. & n.s. \\
\hline \multicolumn{7}{|l|}{ Family origin: } \\
\hline 2 parents "French by birth" & Ref. & Ref. & Ref. & Ref. & Ref. & Ref. \\
\hline At least 1 Algerian imm. parent & $0.833^{* *}$ & 0.099 & 8.46 & $26 \%$ & $13 \%$ & $96 \%$ \\
\hline At least 1 Moroccan imm. parent & $0.750 * *$ & 0.137 & 5.50 & $25 \%$ & $11 \%$ & $84 \%$ \\
\hline At least 1 Tunisian imm. parent & 0.235 & 0.206 & 1.14 & n.s. & n.s. & n.s. \\
\hline At least 1 immigrant parent from Sub-Saharan Africa & $0.428^{*}$ & 0.247 & 1.74 & $19 \%$ & $6 \%$ & $43 \%$ \\
\hline \multicolumn{7}{|l|}{ Family size in 1990 : } \\
\hline $1-2$ children & $-0.206 * *$ & 0.086 & 2.38 & $11 \%$ & $-2 \%$ & $-17 \%$ \\
\hline $3-4$ children & $-0.187 * *$ & 0.086 & 2.18 & $11 \%$ & $-2 \%$ & $-15 \%$ \\
\hline $5-6$ children & Ref. & Ref. & Ref. & Ref. & Ref. & Ref. \\
\hline 7 children or more & $0.356^{* *}$ & 0.132 & 2.69 & $18 \%$ & $5 \%$ & $35 \%$ \\
\hline \multicolumn{7}{|l|}{ Occupation of the household's reference person } \\
\hline Farmer/Farm worker, father 1990 & $-0.266^{*}$ & 0.147 & 1.81 & $10 \%$ & $-3 \%$ & $-24 \%$ \\
\hline Shopkeeper/Craftsman, father 1990 & $-0.212 * *$ & 0.078 & 2.72 & $11 \%$ & $-2 \%$ & $-17 \%$ \\
\hline Manager/teacher/researcher, father 1990 & -0.030 & 0.080 & 0.37 & n.s. & n.s. & n.s. \\
\hline Middle management, father 1990 & $0.110^{*}$ & 0.065 & 1.69 & $15 \%$ & $1 \%$ & $10 \%$ \\
\hline Employee/Clerk, father 1990 & 0.085 & 0.079 & 1.08 & n.s. & n.s. & n.s. \\
\hline Manual worker, father 1990 & Ref. & Ref. & Ref. & Ref. & Ref. & Ref. \\
\hline Domestic employee, other situation 1990 & $0.165^{* *}$ & 0.060 & 2.73 & $16 \%$ & $3 \%$ & $20 \%$ \\
\hline Living in Sensitive Urban Area (1999) & $0.365 * *$ & 0.070 & 5.24 & $18 \%$ & $5 \%$ & $36 \%$ \\
\hline Married 1999 & $-1.039 * *$ & 0.086 & 12.07 & $5 \%$ & $-8 \%$ & $-61 \%$ \\
\hline \multicolumn{7}{|l|}{ Educational attainment - Qualifications 1999} \\
\hline No qualification & $0.919 * *$ & 0.064 & 14.27 & $28 \%$ & $15 \%$ & $109 \%$ \\
\hline Primary Leaving Certificate & $0.656^{* *}$ & 0.205 & 3.19 & $23 \%$ & $10 \%$ & $71 \%$ \\
\hline Secondary School Level ('O’ level) & $0.686^{* *}$ & 0.091 & 7.56 & $23 \%$ & $10 \%$ & $75 \%$ \\
\hline 1st certificate of apprenticeship & $0.383^{* *}$ & 0.070 & 5.51 & $18 \%$ & $5 \%$ & $38 \%$ \\
\hline 2nd certificate of apprenticeship & $0.242 * *$ & 0.072 & 3.35 & $16 \%$ & $3 \%$ & $23 \%$ \\
\hline Baccalaureate ('A’ level) & Ref. & Ref. & Ref. & Ref. & Ref. & Ref. \\
\hline University Education & $-0.439 * *$ & 0.066 & 6.60 & $9 \%$ & $-4 \%$ & $-32 \%$ \\
\hline$\%$ concordance & $8 \%$ & & & & $\mathrm{~N}=$ & 8,823 \\
\hline
\end{tabular}

Source: INSEE, Echantillon démographique permanent 1990-1999.

sociated with the different probabilities $\mathrm{P}$ of uncertainty over the Ho hypothesis of $\beta \mathrm{i}$ being null. If $t_{i}$ is higher than $t$, the Ho hypothesis is rejected.

The situation in sensitive urban areas is becoming increasingly delicate, and data from recent censuses shows that this has been further aggravated in some areas over the past ten years. Social imbalances are a deep-seated phenomenon in French cities, and one that is clearly reflected in the designation of ZUS (Zones urbaines sensiblessensitive urban areas). Urban segregation brings with it urban dislocation, in that it breaks down equality in social spaces, most importantly the workplace. To account for this, it is necessary to consider the history of cities and districts. Moreover, this phenomenon is growing in scale, due to the influx of immigrants to cities (Wacquant 2007). Employment opportunities can differ depending on the street or even the city an applicant comes from, irrespective of neighbourhood. Discrimination generates a dynamic of urban divergence; urban segregation is the 
Table 5. Logistic regression. Frequency of unemployment among young active women (aged 24-29) in 1999 (daughters of two parents who are 'French by birth' v. women with at least one imm. parent from Africa).

\begin{tabular}{|c|c|c|c|c|c|c|}
\hline & $\beta$ & $\sigma \beta$ & $t$ & $P$ & $P-P o$ & $\Delta(\%)$ \\
\hline Constant $=-2.191 * *$ & & 0.080 & 27.50 & $10 \%$ & & \\
\hline \multicolumn{7}{|l|}{ Age (1999) } \\
\hline 24 & $0.278 * *$ & 0.080 & 3.83 & $13 \%$ & $3 \%$ & $28 \%$ \\
\hline 25 & -0.022 & 0.072 & 0.30 & n.s. & n.s. & n.s. \\
\hline 26 & Ref. & Ref. & Ref. & Ref. & Ref. & Ref. \\
\hline 27 & -0.060 & 0.071 & 0.85 & $10 \%$ & $-1 \%$ & $-5 \%$ \\
\hline 28 & $-0.198 * *$ & 0.074 & 2.69 & $8 \%$ & $-2 \%$ & $-16 \%$ \\
\hline 29 & $-0.238 * *$ & 0.080 & 2.99 & $8 \%$ & $-2 \%$ & $-19 \%$ \\
\hline Foreign citizenship 1999 & $0.296^{*}$ & 0.178 & 1.66 & $13 \%$ & $3 \%$ & $29 \%$ \\
\hline \multicolumn{7}{|l|}{ Family origin } \\
\hline 2 parents "French by birth" & Ref. & Ref. & Ref. & Ref. & Ref. & Ref. \\
\hline At least 1 Algerian imm. parent & $0.365 * *$ & 0.115 & 3.18 & $14 \%$ & $4 \%$ & $38 \%$ \\
\hline At least 1 Moroccan imm. parent & $0.261 *$ & 0.155 & 1.68 & $13 \%$ & $3 \%$ & $26 \%$ \\
\hline At least 1 Tunisian imm. parent & 0.145 & 0.243 & 0.60 & n.s. & n.s. & n.s. \\
\hline $\begin{array}{l}\text { At least } 1 \text { immigrant parent from Sub- } \\
\text { Saharan Africa }\end{array}$ & $0.683 * *$ & 0.274 & 2.50 & $18 \%$ & $8 \%$ & $80 \%$ \\
\hline \multicolumn{7}{|l|}{ Family size in 1990} \\
\hline 1-2 children & -0.046 & 0.043 & 2.56 & n.s. & n.s. & n.s. \\
\hline 3-4 children & Ref. & Ref. & Ref. & Ref. & Ref. & Ref. \\
\hline $5-6$ children & $0.207 * *$ & 0.081 & 1.78 & $11 \%$ & $1 \%$ & $13 \%$ \\
\hline 7 children or more & 0.088 & 0.146 & 0.60 & n.s. & n.s. & n.s. \\
\hline \multicolumn{7}{|c|}{ Occupation of the household's reference person } \\
\hline Farmer/Farm worker, father 1990 & -0.223 & 0.149 & 1.50 & n.s. & n.s. & n.s. \\
\hline Shopkeeper/Craftsman, father 1990 & $-0.310 * *$ & 0.080 & 3.89 & $8 \%$ & $-2 \%$ & $-25 \%$ \\
\hline Mgr./teacher/researcher, father 1990 & 0.007 & 0.081 & 0.09 & n.s. & n.s. & n.s. \\
\hline Middle management, father 1990 & $-0.203 * *$ & 0.068 & 2.96 & $8 \%$ & $-2 \%$ & $-17 \%$ \\
\hline Employee/Clerk, father 1990 & -0.029 & 0.082 & -0.36 & $10 \%$ & $0 \%$ & $-3 \%$ \\
\hline Manual worker, father 1990 & Ref. & Ref. & Ref. & Ref. & Ref. & Ref. \\
\hline Domestic empl, other situation 1990 & 0.031 & 0.062 & 0.50 & n.s. & n.s. & n.s. \\
\hline Living in Sensitive Urban Area (1999) & $0.272 * *$ & 0.075 & 3.65 & $13 \%$ & $3 \%$ & $27 \%$ \\
\hline Married 1999 & $-0.175 * *$ & 0.052 & 3.40 & $9 \%$ & $-1 \%$ & $-15 \%$ \\
\hline \multicolumn{7}{|l|}{ Number of own children (1999) } \\
\hline None & Ref. & Ref. & Ref. & Ref. & Ref. & Ref. \\
\hline 1 child & $0.708 * *$ & 0.058 & 12.30 & $18 \%$ & $8 \%$ & $84 \%$ \\
\hline 2 children & $0.694 * *$ & 0.050 & 13.88 & $18 \%$ & $8 \%$ & $82 \%$ \\
\hline \multicolumn{7}{|c|}{ Educational attainment - Qualifications 1999} \\
\hline No qualification & $1.149 * *$ & 0.073 & 15.85 & $26 \%$ & $16 \%$ & $159 \%$ \\
\hline Primary Leaving Certificate & $1.286 * *$ & 0.259 & 4.96 & $29 \%$ & $19 \%$ & $186 \%$ \\
\hline Secondary School Level ('O’ level) & $0.809 * *$ & 0.097 & 8.33 & $20 \%$ & $10 \%$ & $100 \%$ \\
\hline 1st certificate of apprenticeship & $0.778 * *$ & 0.079 & 9.88 & $20 \%$ & $10 \%$ & $95 \%$ \\
\hline 2nd certificate of apprenticeship & $0.713 * *$ & 0.070 & 10.13 & $19 \%$ & $9 \%$ & $85 \%$ \\
\hline Baccalaureate ('A' level) & $0.428 * *$ & 0.061 & 7.07 & $15 \%$ & $5 \%$ & $46 \%$ \\
\hline University Education & Ref. & Ref. & Ref. & Ref. & Ref. & Ref. \\
\hline$\%$ concordance & $68 \%$ & & & & & $\mathrm{~N}=15,481$ \\
\hline
\end{tabular}

Source: INSEE, Echantillon démographique permanent 1990-1999.

spatial consequence of social disequilibrium. This socio-spatial polarization testifies to a long period of persistent unemployment. Living in sensitive urban areas increases the probability of being jobless by about 35 per cent (Tables 4, 5, and 6). The 1999 census also reveals other characteristics: the percentage of foreigners in the population (which averages 5.6 per cent nationally) is much higher in the ZUS (16.5 per cent).

Young people who only have one relative (generally the father) who is an immigrant from Sub-Saharan Africa do not seem to be significantly penalized (Table 6). The results are very interesting, as can be seen below. In the field of discrimination research, the ethnic background of young people is often defined in terms of ethnic background of one of the parents (generally the father). We decided to widen this definition and include the situations 
of children of exogamous parents. Among young men and women, those whose parents were both born in North Africa experience more difficulty in finding a job. Young men with two immigrant parents from Sub-Saharan Africa are also obviously the object of discrimination. Young men who have immigrated from the Maghreb have more difficulties when their father (from whom they often "inherit" the patronymic surname) is an immigrant, whereas children of a Maghrebian mother and a father who is "French by birth" are faced with fewer difficulties (Table 6). The patronymic surname has an undeniable effect on the probability of being recruited, as Amadieu has shown with reference to France (Amadieu 2005).

Table 6. Logistic Regression. Frequency of unemployment among young active men (aged 23-29) in 1999.

\begin{tabular}{|c|c|c|c|c|c|c|}
\hline & $\beta$ & $\sigma \beta$ & $t$ & $P$ & $P-P o$ & $\Delta(\%)$ \\
\hline Constant $=-1.392 * *$ & & 0.138 & 10.06 & $20 \%$ & & \\
\hline \multicolumn{7}{|l|}{ Age (1999) } \\
\hline 23 & $0.258 * *$ & 0.074 & 3.47 & $24 \%$ & $4 \%$ & $22 \%$ \\
\hline 24 & $0.204 * *$ & 0.074 & 2.77 & $23 \%$ & $3 \%$ & $17 \%$ \\
\hline 25 & 0.056 & 0.069 & 0.81 & n.s. & n.s. & n.s. \\
\hline 26 & Ref. & Ref. & Ref. & Ref. & Ref. & Ref. \\
\hline 27 & $-0.182 * *$ & 0.069 & 2.62 & $19 \%$ & $-1 \%$ & $-5 \%$ \\
\hline 28 & $-0.276^{* *}$ & 0.072 & 3.86 & $17 \%$ & $-3 \%$ & $-15 \%$ \\
\hline 29 & $-0.426^{* *}$ & 0.077 & 5.54 & $16 \%$ & $-4 \%$ & $-18 \%$ \\
\hline Foreign born & 0.122 & 0.125 & 0.97 & n.s. & n.s. & n.s. \\
\hline Foreign citizenship 1999 & -0.091 & 0.140 & 0.65 & n.s. & n.s. & n.s. \\
\hline \multicolumn{7}{|l|}{ Family origin } \\
\hline 2 Maghrebian parents*** & $1.060^{* *}$ & 0.110 & 9.67 & $42 \%$ & $22 \%$ & $110 \%$ \\
\hline Maghrebian father, mother "French by birth" & $0.440 * *$ & 0.211 & 2.08 & $28 \%$ & $8 \%$ & $40 \%$ \\
\hline Maghrebian mother, father "French by birth" & 0.355 & 0.584 & 0.61 & n.s. & n.s. & n.s. \\
\hline 2 parents from Sub-Saharan Africa $* * *$ & $0.605 * *$ & 0.293 & 2.07 & $31 \%$ & $11 \%$ & $57 \%$ \\
\hline 1 parent from Sub-Saharan Africa & 0.544 & 0.594 & 0.92 & n.s. & n.s. & n.s. \\
\hline at least 1 Turkish parent & 0.167 & 0.222 & 0.74 & n.s. & n.s. & n.s. \\
\hline 2 parents "French by birth" & 0.025 & 0.077 & 0.32 & n.s. & n.s. & n.s. \\
\hline Other origin & Ref. & Ref. & Ref. & Ref. & Ref. & Ref. \\
\hline \multicolumn{7}{|l|}{ Family size in 1990} \\
\hline $1-2$ children & $-0.137^{*}$ & 0.084 & 1.64 & $18 \%$ & $-2 \%$ & $-11 \%$ \\
\hline 3-4 children & $-0.149 *$ & 0.084 & 1.79 & $18 \%$ & $-2 \%$ & $-11 \%$ \\
\hline $5-6$ children & Ref. & Ref. & Ref. & Ref. & Ref. & Ref. \\
\hline 7 children or more & $0.379 * *$ & 0.134 & 2,83 & $27 \%$ & $7 \%$ & $34 \%$ \\
\hline \multicolumn{7}{|l|}{ Occupation of the household's reference person } \\
\hline Farmer/Farm worker, father 1990 & $-0.309 * *$ & 0.141 & 2.19 & $15 \%$ & $-4 \%$ & $-22 \%$ \\
\hline Shopkeeper/Craftsman, father 1990 & $-0.218 * *$ & 0.075 & 2.91 & $17 \%$ & $-3 \%$ & $-16 \%$ \\
\hline Manager/teacher/researcher, father 1990 & $0.194 * *$ & 0.079 & 2.46 & $23 \%$ & $3 \%$ & $16 \%$ \\
\hline Middle management, father 1990 & $0.191 * *$ & 0.063 & 2.96 & $23 \%$ & $3 \%$ & $16 \%$ \\
\hline Employee/Clerk, father 1990 & $0.146^{*}$ & 0.077 & 1.90 & $22 \%$ & $2 \%$ & $12 \%$ \\
\hline Manual worker, father 1990 & Ref. & Ref. & Ref. & Ref. & Ref. & Ref. \\
\hline Domestic employee, other situation 1990 & $0.214 * *$ & 0.059 & 3.63 & $24 \%$ & $4 \%$ & $18 \%$ \\
\hline Living in Sensitive Urban Area 1999 & $0.388 * *$ & 0.067 & 5.75 & $27 \%$ & $7 \%$ & $35 \%$ \\
\hline \multicolumn{7}{|l|}{ Educational attainment - Qualifications 1999} \\
\hline No qualification & $0.335 * *$ & 0.087 & 3.86 & $26 \%$ & $6 \%$ & $30 \%$ \\
\hline Primary Leaving Certificate & -0.037 & 0.205 & 0.18 & n.s. & n.s. & n.s. \\
\hline Secondary School Level ('O’ level) & Ref. & Ref. & Ref. & Ref. & Ref. & Ref. \\
\hline 1st certificate of apprenticeship & $-0.358 * *$ & 0.090 & 3.97 & $15 \%$ & $-5 \%$ & $-26 \%$ \\
\hline 2nd certificate of apprenticeship & $-0.488 * *$ & 0.093 & 5.27 & $13 \%$ & $-7 \%$ & $-33 \%$ \\
\hline Baccalaureate ('A' level) & $-0.516^{* *}$ & 0.088 & 5.90 & $13 \%$ & $-7 \%$ & $-35 \%$ \\
\hline University Education & $-0.849 * *$ & 0.090 & 9.42 & $10 \%$ & $-10 \%$ & $-52 \%$ \\
\hline$\%$ concordance & $6 \%$ & & & & & $=21,031$ \\
\hline
\end{tabular}

Source: INSEE, Echantillon démographique permanent 1990-1999.

Note: $* * *$ or single-parent family with same origin. 


\section{Discussion}

It is not easy for young people of foreign origin in France to enter the labour market. The Permanent Demographic Sample helps reveal the existence of particularly difficult labour market situations confronting certain types of immigrant and especially those who originate from the Maghreb and Sub-Saharan Africa. It is important to analyze the problems they experience in light of the major role played by qualifications obtained in the education system, which mediates between the significance of family origins and ultimate professional outcomes. Although gaining citizenship is often an important stage which overcomes certain discriminatory barriers, the lesson from the French experience is that integration at the cultural and political levels is not enough. Cultural and economic integration must be interlinked if they are to be successful.

The crisis in the suburbs witnessed in November 2005 also showed that discrimination is also experienced by the young French population. Exclusion can take on various forms, and reveals the inability of the system to translate formal equality of rights into true equality. Most immigrant descendants feel French, but are not always perceived as such by others. The phenomenon of discrimination further exacerbates the phenomenon of urban segregation and impacts, in particular, access to work and housing. There is a very great need for further quantitatively based social studies of the situation of the children of immigrants in France (Constant 2005). The law of 2001 has strengthened the legal basis for such an undertaking. Finally, the effectiveness of targeted policies could be established insofar as they aim at integration, defined in a narrow sense.

France should recognize the social embeddedness of immigrants and their families. The results of statistical studies show that the creation of the Haute autorité de lutte contre les discriminations et pour l'égalité (an authority responsible for combating discrimination and promoting equality) in 2005 responded to a genuine need within French society. The remit of the authorities should encompass not only discrimination linked to national or ethnic origin, but also discrimination on the basis of urban origin or any other grounds. Research into the integration of migrants and their children should be encouraged and, in many cases, conducted on the basis of more advanced econometric techniques and more appropriate data. However, the use of a small number of criteria such as previous and current citizenship, or the birthplace of the individual or his or her parents is sufficient, when coupled with appropriate longitudinal surveys, to undertake statistical studies that indicate the different employment outcomes experienced by various populations.

\section{References}

Amadieu, J-F. 2005. Employment Discrimination: The Situation Today and Future Research Required. Paper presented at Columbia University, New York, May. Available online at http:/ / cergors.univ-paris1.fr/ docsatelecharger/employment per cent20discrimination.pdf.

Arrow, K.J. 1972. Models of job discrimination, in Racial Discrimination in Economic Life, edited by A.H. Pascal. Lexington, MA: D.C. Heath, pp. 83-102.

Blum, A. 2002. Resistance to identity categorization in France, in Census and Identity: The Politics of Race, Ethnicity, and Language in National Censuses, edited by D. Kertzer and D. Arel. Cambridge-New York: Cambridge University Press, pp. 121-147.

Borjas, G.J. 1990. Friends or Strangers. New York: Basic Books.

Brinbaum, Y., and P. Werquin. 1997. Enfants d'immigrés : un accès au travail difficile, des itinéraires spécifiques. Informations sociales 62:32-41.

Constant, A.F. 2005. Immigrant adjustment in France and impacts on the natives, in European Migration: What Do We Know ?, edited by K.F. Zimmermann. Oxford: Oxford University Press, pp. 263-302. 
Doomernik, J. 1998. The Effectiveness of Integration Policies Towards Immigrants and Their Descendants in France, Germany and The Netherlands. International Migration Papers 27. Geneva: International Labour Organization. Available online at http://www.ilo.org/public/english/protection/migrant/download/research/imp/imp27.pdf.

Elmslie, B., and S. Sedo. 1996. Discrimination, social psychology and hysteresis in labor markets. Journal of Economic Psychology 17(4):465-478.

Fougère, D., and M. Safi. 2009. Naturalization and employment of immigrants in France (1968-1999). International Journal of Manpower 30:83-96.

Frickey, A., J. Murdoch, and J-L. Primon. 2005. From higher education to employment-inequalities between ethnic backgrounds in France. European Education 37(4):61-74.

Fitoussi, J-P., E. Laurent, and J. Maurice. 2004. Urban segregation and social integration. The Newsletter of the French Council of Economic Analysis I-02:1-4.

Goldberg, M.S. 1978. Biased screening and discrimination in the labor market. American Economic Review 65:918922.

King, R., T. Fielding, and T. Warnes. 2004. Gender, Age and Generations. Sussex: Sussex Centre for Migration and population Studies, University of Sussex. (also at www.imiscoe.org/workingpapers/documents/gender_age_ and_generations.pdf)

Maxwell, R. 2010. Political participation in France among non-European origin migrants: Segregation or integration? Journal of Ethnic and Migration Studies 36(3):425-443.

Meurs, D., A. Pailhé, and P. Simon. 2007. The persistence of intergenerational inequalities linked to immigration: Labour market outcomes for immigrants and their descendants in France. Population-E 61(5-6):645-682.

Oppenheimer, D.B. 2008. Why France needs to collect data on racial identity ... in a French way. Hastings International and Comparative Law Review 31(2):735-752.

Phelps, E. 1972. The statistical theory of racism and sexism. American Economic Review 62(4):639-651.

Richard, J-L. 1997a. Unemployment among young people of foreign-origin in France: Ways of measuring discrimination, in On the Way to a Multicultural Society? edited by Swiss Federal Statistical Office. Bern: SFSO, pp. 101-135.

1997b. Dynamiques démographiques et socio-économiques de l'intégration des jeunes générations d'origine immigrée en France: Etude à caractère longitudinal, $\mathrm{PhD}$ diss., Institut d'études politiques de Paris.

2003. Immigration, Integration and Demographic Forecasts in the European Context: Conclusions and Implications of The French Commissariat Général Du Plan Report. Proceedings of the European Social Policy Conference, Copenhagen.

- 2004. Partir ou rester? Paris: Presses universitaires de France.

Safi, M. 2008. The immigrant integration process in France: Inequalities and segmentation. Revue française de sociologie 49(3):3-44.

Silberman, R. 2002. Les enfants d'immigrés sur le marché du travail, in Immigration, marché du travail, intégration, edited by F. Héran, M. Aoudai, and J-L. Richard. Paris: La Documentation Française, pp. 297-311.

Silberman, R., and I. Fournier. 1999. Les enfants d'immigrés sur le marché du travail. Les mécanismes d'une discrimination sélective. Formation Emploi 65:31-55. 
Simon, P., and M. Clément. 2006. Comment décrire la diversité des origines en France? Une enquête exploratoire sur les perceptions des salariés et des étudiants. Populations et société 425:1-4.

Tiberj, V., and S. Brouard. 2005. Français comme les autres? Paris: Presses de Sciences Po.

Wacquant, L. 2007. Urban Outcasts: A Comparative Sociology of Advanced Marginality. Cambridge: Polity. 